Dept. of Food Hygiene,

Fac. of Vet. Med., Assiut Univ.

\title{
ISOLATION OF LISTERIA MONOCYTOGENES AND OTHER LISTERIA SPECIES FROM MILK AND SOME DAIRY PRODUCTS
}

(With 2 Tables)

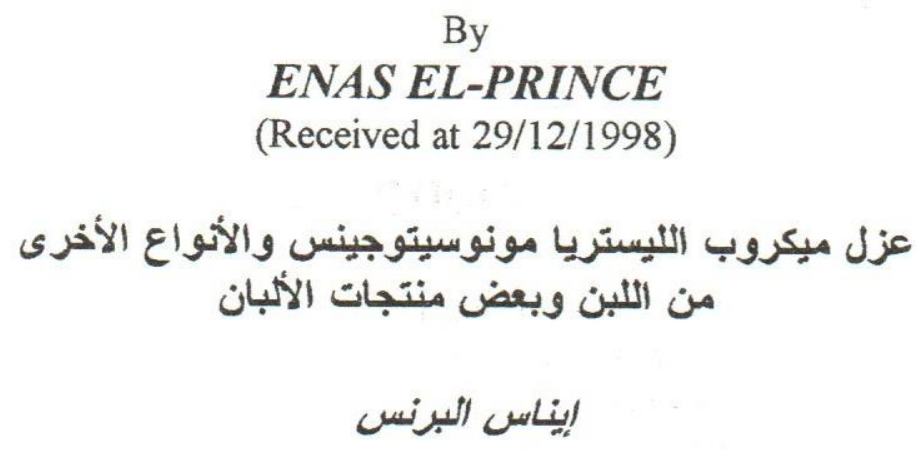

يعتبر مرض الــ Listeriosis من الأمر اض الخطيرة التى قد تصيب الانسان نتيجة لتتاول

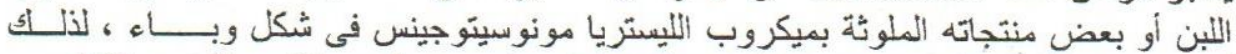

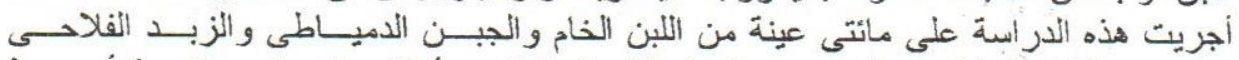

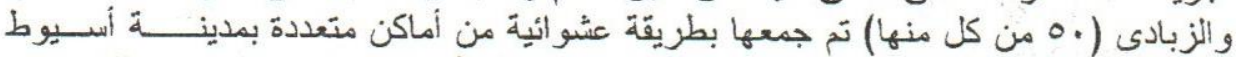

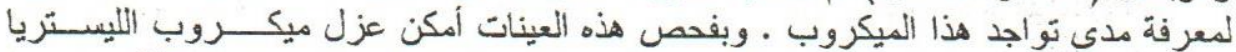

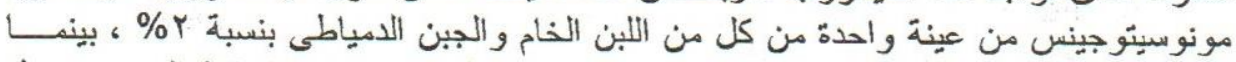

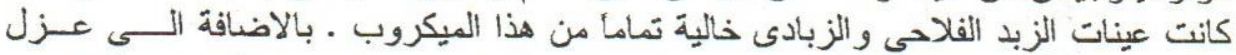

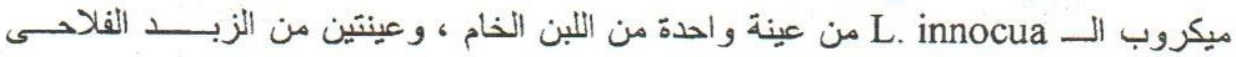

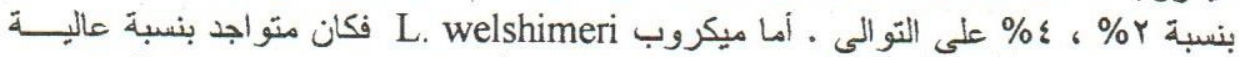

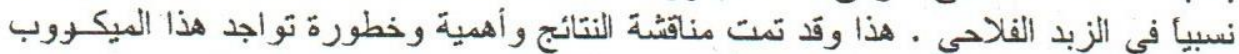
على صحة الانسان وما يجب إتخاذه لمنع إنتشاره .

\section{SUMMARY}

Two-hundred random samples of raw milk, Domiati cheese, cooking butter and yoghurt (50 each) were collected from street vendors, different local supermarkets, dairy farms and dairy shops in Assiut city, Egypt. The samples were examined bacteriologically for the presence of $\mathrm{L}$. 
monocytogenes and other Listeria spp. The obtained results revealed that L. monocytogenes was found in one sample $(2 \%)$ of both raw milk and Domiati cheese, while the organism failed detection in the examined cooking butter and yoghurt samples. However, L. innocua could be isolated from one $(2 \%)$ and $2(4 \%)$ of the examined raw milk and cooking butter samples, respectively. Also, $4(8 \%)$ of cooking butter samples proved to harbour L. welshimeri. The public health importance of Listeria spp. in milk and dairy products and the suggestive measures were discussed.

Keywords: Listeria monocytogenes, Listeria species, Milk, Dairy products.

\section{INTRODUCTION}

L. monocytogenes is a foodborne pathogen which is now very well known by individuals concerned with food safety (Farber, 1993). This organism is ubiquitous in nature and is widely spread in the environment, where it may survive for long periods (Eley, 1996). It has been associated with serious disease "Listeriosis" in man. The typical symptoms of listeriosis are septicaemia, meningitis or abortion in pregnant women, which occur most commonly in neonates and immunosuppressed patients (Miller et al., 1997 and Arizcun et al., 1998). Before the 1980s, L. monocytogenes was of concern primarily as a cause of abortion and encephalitis in animals such as cattle, sheep, goats, buffaloes and chickens (Gitter et al., 1980 and Ralovitch, 1984). Moreover, in dairy cattle L. monocytogenes can cause mastitis leading to excretion of the organism in milk, subsequently, transmitted to human from these infected animals or through consumption of Listeria-contaminated foods (Papageorgiou and Marth, 1989). Recently, milk and dairy products are the most often incriminated as responsible for listeriosis than other types of food (Franco Abuin et al., 1996). It has been well documented that three foodborne outbreaks of listeriosis were associated with consumption of pasteurized milk in Massachusetts, USA in 1983 (Fleming et al., 1985), soft Mexicanstyle cheese in California, USA in 1985 (James et al., 1985) and soft cheese of the Vacherin Mont d'Or type in Switzerland in 1987 (Papageorgiou and Marth, 1989). Furthermore, many surveys have been conducted and have shown that L. monocytogenes or other Listeria spp. 
to be commonly isolated from milk and dairy products worldwide (Farber et al., 1988; Massa et al., 1990; Loncarevic et al., 1995; Hassan, 1996 and Aman and Ahmed, 1997). The incidence of L. monocytogenes in raw milk has been reported to be between 0 and $45.3 \%$ (Farber and Peterkin, 1991). Also, the number of this pathogen in soft cheese may be as high as $10^{6} / \mathrm{g}$ (Terplan et al., 1986; Farber et al., 1987 and Gilbert and Pini, 1988). Fortunately, many of the bacterium present in cream are removed with butter milk during butter manufacture and the $\mathrm{L}$. monocytogenes population is reduced by $97.5 \%$ (Olsen et al., 1988). Additionally, L. seeligeri and $\mathrm{L}$. welshimeri have been documented to cause infections in human (Rocourt et al., 1986 and Andre and Genicot, 1987). The use of Listeria spp. other than L. monocytogenes as indicators of the presence of that pathogen has been proposed (WHO, 1988).

Owing to the several outbreaks of listeriosis in the past few years, the hygienic relevance of the presence of Listeria spp. in food has moved to a fundamentally new level (Url et al., 1993). This fact estimates us to determine the incidence of L. monocytogenes and other Listeria spp. in raw milk and in some dairy products.

\section{MATERIAL and METHODS}

\section{Collection of samples:}

Two-hundred random samples of raw milk, Domiati cheese, cooking butter and yoghurt (50 each) were collected from street vendors, different local supermarkets, dairy farms and dairy shops in Assiut city, Egypt. The samples were maintained at chill temperatures during transportation to the laboratory and tested for the presence of $\mathrm{L}$. monocytogenes and other Listeria spp.

\section{Isolation and identification of Listeria spp.:}

The most widely used approaches are based upon (FDA) method (Lovett et al., 1987). $25 \mathrm{ml}$ or $25 \mathrm{~g}$ of each prepared sample were added to $225 \mathrm{ml}$ Listeria Enrichment Broth (LEB) and incubated at $35^{\circ}$ for 48 $\mathrm{h}$, then loopfuls were streaked onto Listeria Selective Medium (LSMOxford Formulation). After incubation at $35^{\circ} \mathrm{C}$ for $48 \mathrm{~h}$. The suspected colonies were picked up for purification. Identification and species differentiation were done according to Johnson et al. (1990) including carbohydrate fermentation, B-haemolysis on blood agar and CAMP test. 


\section{RESULTS}

The obtained results were recorded in Tables ( $1 \& 2)$.

Table 1. Isolation of L. monocytogenes from the examined samples.

\begin{tabular}{|l|c|c|c|}
\hline \multirow{2}{*}{$\begin{array}{c}\text { Type of } \\
\text { samples }\end{array}$} & \multirow{2}{*}{$\begin{array}{c}\text { No. of examined } \\
\text { samples }\end{array}$} & \multicolumn{2}{|c|}{ Positive samples } \\
\cline { 3 - 4 } & 50 & No. & $\%$ \\
\hline Raw milk & 50 & 1 & $2 \%$ \\
\hline Domiati cheese & 50 & 0 & - \\
\hline Cooking butter & 50 & 0 & - \\
\hline Yoghurt & &
\end{tabular}

Table 2. Isolation of other Listeria species from the examined samples.

\begin{tabular}{|l|c|c|c|c|c|c|}
\hline \multirow{3}{*}{$\begin{array}{c}\text { Type of } \\
\text { samples }\end{array}$} & \multicolumn{6}{|c|}{ No. of positive samples } \\
\cline { 2 - 7 } & \multicolumn{2}{|c|}{ L.monocytogenes } & \multicolumn{2}{c|}{ L. innocua } & \multicolumn{2}{c|}{ L. welshimeri } \\
\cline { 2 - 7 } & No./50 & $\%$ & No./50 & $\%$ & No./50 & $\%$ \\
\hline Raw milk & 1 & $2 \%$ & 1 & $2 \%$ & 0 & - \\
\hline Domiati cheese & 1 & $2 \%$ & 0 & - & 0 & - \\
\hline Cooking butter & 0 & - & 2 & $4 \%$ & 4 & $8 \%$ \\
\hline Yoghurt & 0 & - & 0 & - & 0 & - \\
\hline
\end{tabular}

\section{DISCUSSION}

The results in Table 1 revealed that $\mathrm{L}$. monocytogenes could be detected in $1(2 \%)$ of each of raw milk and Domiati cheese samples, while the organism failed detection in the examined samples of cooking butter and yoghurt. Similar findings were obtained by Husu et al. (1990) and Rola et al. (1994). However, higher percentages were stated by Ahmed (1990), Saito et al. (1991), Banks (1994), Abdel-Hady et al. (1996) and Hassan (1996). On the other hand, L. monocytogenes was recovered from only $0.2 \%$ of raw milk samples examined by Hassanein (1994). The main source of this microorganism in milk is probably faecal contamination or diseased dairy animal which can excrete this pathogen in their milk (El-Gazzar and Marth, 1991). L. monocytogenes also is able 
to grow and increase in numbers during storage in farm bulk milk tanks (Lovett et al., 1987).

Concerning Domiati cheese samples, similar findings were obtained by D'Errico et al. (1990), Massa et al. (1990), Fathi and Saad (1992) and Banks (1994). While, Aman and Ahmed (1997) found that L. monocytogenes could not be isolated from the examined cheese samples. However, Bannerman and Bille (1988) stated that L. monocytogenes was recovered from $14.3 \%$ of cheese samples. Although, the increased amount of salt added to Domiati cheese retard L. monocytogenes growth (Ahmed et al., 1989 and Marth, 1993), but many outbreaks of listeriosis were associated with different types of cheese (James et al. 1985 and Papageorgiou and Marth, 1989). Since, the contamination of soft cheese is often caused by insufficiently sanitized equipments (Terplan et al., 1990).

It is obvious from the results presented in Table 2 that all Listeria isolates from the samples of milk and dairy products were identified as $\mathrm{L}$. monocytogenes, L. innocua and L. welshimeri. It is clear that $1(2 \%)$ of raw milk and $2(4 \%)$ of cooking butter samples were positive for $\mathrm{L}$. innocua. However, L. welshimeri could be isolated only from $4(8 \%)$ samples of cooking butter. Nearly similar results were recorded by Saito et al. (1991), while D'Errico et al. (1990), El-Leboudy and Fayed (1992) and Aman and Ahmed (1997) stated higher isolation rate of L. innocua from raw milk samples. Milk may be easily contaminated from listeric animals as well as from the environmental surroundings and dirty equipments (WHO, 1992).

Regarding cooking butter samples, Adams and Moss (1995) reported that $\mathrm{L}$. welshimeri was associated with human illness. Although, many of bacteria found in cream are removed with the butter milk during butter manufacturing, Listeria organism is able to grow during the initial stages of storage (Olsen et al., 1988).

In case of yoghurt samples, L. monocytogenes or other Listeria spp. could not be detected. This finding go parallel with the results achieved by Rola et al. (1994). The failure of these microorganisms to grow could be attributed to lactic acid production and the resultant lower $\mathrm{pH}$ value (Ahmed, 1989).

It would appear from this investigation that contamination of milk and some dairy products by L. monocytogenes from the viewpoint of a 
potential health hazard should not be ignored. The contamination may occur through unsufficient heat treated raw milk or through contaminated equipments used for preparation and distribution of the dairy products. Therefore, stringent hygienic measures must be followed in dairy plants and farms.

\section{REFERENCES}

Abdel-Hady, H.M.; Moawad, A.A. and Abouzeid, A.M. (1996): Validation of simple method for rapid detection of $\mathrm{L}$. monocytogenes in raw milk and kareish cheese. $4^{\text {th }}$ Sci. Cong. Vet. Med. J. Giza, 44: 209-213.

Adams, M.R. and Moss, M.O. (1995): Food Microbiology. The Royal Soc. of Chem., Cambridge.

Ahmed, A.A-H. (1989): Behaviour of L. monocytogenes during preparation and storage of yoghurt. Assiut Vet. Med. J., 22: 7680.

Ahmed, A.A-H.; Ahmed, S.H.; Moustafa, M.K. and Saad, N.M. (1989): Growth and survival of L. monocytogenes during manufacture and storage of Damietta cheese. Assiut Vet. Med. Med. J., 22: 88-94.

Ahmed, M.E. (1990): Isolation of L. monocytogenes from farm bulk milk cans. Egypt. J. Vet. Sci., 27: 109-115.

Aman, I.M. and Ahmed, H.F. (1997): Incidence and survival of some foodborne pathogens in milk and cheese. J. Egypt. Vet. Med. Assoc., 57: 151-163.

Andre, P. and Genicot, A. (1987): First isolation of L. welshimeri from human beings. Zentrabl. Bakteriol. Parasitend. Infektionskr. Hyg. Abl. 1 Orig. Reibe A, 263: 605-606.

Arizcun, C.; Vasseur, C. and Labadie, J.C. (1998): Effect of several decontamination procedures on $\mathrm{L}$. monocytogenes growing in biofilms. J. Food Prot., 61 (6): 731-734.

Banks, W. (1994): Microbiology of milk. Milk Industry-UK: Technical and Processing Suppl., 96: 18-20.

Bannerman, E.S. and Bille, J.J. (1988): A new selective medium for isolating Listeria spp. from heavily contaminated material. Appl. Environ. Microbiol., 54: 165-167. 
D'Errico, M.M.; Villari, P.; Grasso, G.M.; Romano, F. and Angelillo, I.F. (1990): Isolation of Listeria spp. from milk and cheese. Rivista della Societa Italiana di Scienza dell'a Alimentazione, 19: 47-52. Dairy Sci. Abst., 52: 929 (1990).

El-Gazzar, F.F. and Marth, E.H. (1991): L. monocytogenes and listeriosis related to milk, milk products and dairy ingredients. A review: Milchwissenschaft, 46 (2): 82-88.

El-Leboudy, A.A. and Fayed, M.A. (1992): Incidence of listeria in raw milk. Assiut Vet. Med. J., 27: 134-146.

Eley, A.R. (1996): Microbial Food Poisoning. $2^{\text {nd }}$ (ed.) Chapman \& Hall, London, UK.

Farber, J.M. (1993): Current research on L. monocytogenes in foods: an Overview. J. Food Prot., 56 (7): 640-643.

Farber, J.M. and Peterkin, P.I. (1991): L. monocytogenes, a food-borne pathogen. Microbiol. Rev., 55: 476-511.

Farber, J.M.; Johnston, M.A.; Purvis, U. and Loit, A. (1987): Surveillance of soft and semi-soft cheeses for the presence of Listeria spp. Intern. J. Food Microbiol., 5: 157-163.

Farber, J.M.; Sanders, G.W. and Malcolm, S.A. (1988): The presence of Listeria spp. in raw milk in Ontario. Can. J. Microbiol., 34: 95100 .

Fathi, Sh.M. and Saad, N.M. (1992): A survey of some selected food items for the presence of L. monocytogenes and other Listeria spp. Assiut Vet. Med. J., 27 (54): 114-120.

Fleming, D.W.; Cochi, S.L.; MacDonald, K.L.; Brondum, J.; Hayes, P.S.; Plikaytis, B.D.; Holmes, M.B.; Audurier, A.; Broome, C.V. and Reingold, A.L. (1985): Pasteurized milk as a vehicle of infection in an outbreak of listeriosis. N. Engl. J. Med., 312: 404-407.

Franco Abuin, C.M.; Quinto Fernandez, E.J.; Fente Sampayo, C.; Rodriguez Otero, J.L.; Dominguez Rodriguez, L. and Cepeda Saez, A. (1996): Incidence of Listeria spp. in the environment of a cheese processing plant throughout one year. Arch. für Lebensmittelhygiene, 47: 25-27.

Gilbert, R.J. and Pini, P.N. (1988): Listeriosis and foodborne transmission. Lancet, II, 472-473. 
Gitter, M.; Bradley, R. and Blampied, P.H. (1980): L. monocytogenes infection in bovine mastitis. Vet. Rec., 107: 390-393.

Hassan, N.M. (1996): Incidence of L. monocytogenes in milk and some dairy products. $\mathrm{Ph}$. D. Thesis, Fac. Vet. Med., Cairo Univ., Egypt.

Hassanein, R.A-H. (1994): Epidemiological studies on the occurrence of listeria infection in animals and man. M.V.Sc. Thesis, Fac. Vet. Med., Assiut Univ., Egypt.

Husu, J.R.; Seppanen, J.T.; Sivela, S.K. and Rauramaa, A.L. (1990): Contamination of raw milk by L. monocytogenes on dairy farms. J. Vet. Med. B. 37: 268-275.

James, S.M.; Fannin, L.; Agree, B.A.; Hall, B.; Parker, E.; Vogt, J.; Run, G.; Williams, J.; Lieb, L.; Salminenh, C.; Prendergast, T.; Wemer, S.B. and Chin, J. (1985): Listeriosis outbreak associated with Mexican-style cheese-California. Morbid. Mortal. Weekly Rep., 34: 357-359.

Johnson, J.L.; Doyle, M.P. and Cassens, R.G. (1990): L. monocytogenes and other Listeria spp. in meat and meat products. A review. J. Food Prot. 53 (1): 81-91.

Loncarevic, S.; Danielsson-Tham, M.L. and Tham, W. (1995): Occurrence of L. monocytogenes in soft and semi-soft cheeses in retail outlets in Sweden. Intern. J. Food Microbiol., 26: 245250.

Lovett, J.; Francis, D.W. and Hunt, J.M. (1987): L. monocytogenes in raw milk: Detection, incidence, and pathogenicity. J. Food Prot., 50 (3): 188-192.

Marth, E.H. (1993): Growth and survival of L. monocytogenes, Sal. species and $\mathrm{S}$. aureus in the presence of sodium chloride. Dairy Food Environ. Sanit., 13: 14-18.

Massa, S.; Cesaroni, D.; Poda, G. and Trovatelli, L.D. (1990): The incidence of Listeria spp. in soft cheeses, butter and raw milk in the province of Bologna. J. Appl. Bacteriol., 68: 153-156.

Miller, A.J.; Whiting, R.C. and Smith, J.L. (1997): Use of risk assessment to reduce listeriosis incidence. Food Technol., 51: 100-103. 
Olsen, J.A.; Yousef, A.E. and Marth, E.H. (1988): Growth and survival of L. monocytogenes during making and storage of butter. Milchwissenschaft, 43: 487-489.

Papageorgiou, D.K. and Marth, E.H. (1989): Fate of L. monocytogenes during the manufacture, ripening and storage of Feta cheese. J. Food Prot., 52: 82-87.

Ralovitch, B. (1984): Listeriosis Research: present situation and perspective. Akademaii kiado: Budapest.

Rola, J.; Kwiatek, K.; Wojton, B. and Michalski, M. (1994): Incidence of L. monocytogenes in raw milk and milk products. Medycyna Weterynaryjna., 50: 323-325. Dairy Sci. Abst., 57: 925 (1994).

Rocourt, J.; Hof, H.; Schnettenbrunner, A.; Malinverni, R. and Brille, J. (1986): Meningite purulente aige a L. seeligeri chez un adulte immunocompetente. Schweiz. Med. Wochenschr., 116: 248251.

Saito, A.; Tokumaru, Y.; Masak, M.; Taya, T. and Aoki, A. (1991): Evaluation of enrichment and plating media for the isolation of L. monocytogenes from raw milk and contamination of raw milk by listeria. J. Jpn. Vet. Med. Assoc., 44 (4): 378-383.

Terplan, G.; Schoen, R.; Springmeyer, W.; Degle, I. and Becker, H. (1986): Occurrence, behaviour and significance of Listeria in milk and dairy products. Arch. für Lebensmittelhygiene, 37: 129-156.

Terplan, G.; Steinmeyer, S.; Becker, H. and Friedrich, K. (1990): Nachweis von Listeria in Milch und Milchprodukten-ein Beitrag zum Stand 1990. Arch. für Lebensmittelhygiene, 41: 102-106.

Url, B.; Heitzer, A. and Brandl, E. (1993): Determination of Listeria in dairy and environmental samples: Comparison of a cultural method and a calorimetric nucleic acid hybridization assay. J. Food Prot., 56 (7): 581-584, 592.

World Health Organization (1988): Foodborne Listeriosis. Bull., WHO, 66: 421-428.

World Health Organization (1992): WHO surveillance programme for control of foodborne infections and intoxications in Europe. New Letter, 35: 1-4 
